Ewa Nowina-Sroczyńska

ORCID: https://orcid.org/0000-0001-6917-0356

Instytut Etnologii i Antropologii Kulturowej

Uniwersytet Łódzki

\title{
Moc filmowego obrazu. Herzog i epifanie ${ }^{1}$
}

\section{The power of the film image. Herzog and epiphanies ${ }^{2}$}

\begin{abstract}
The author explains the reasons why she is seeking ethnographic films outside of ethnography. She writes about the role and status of ethnographic film on the basis of three documentary films by Werner Herzog, analyzing them from an anthropological perspective. She traces the director's postulate concerning the inadequacy of the created images (including film images) to the state of civilization in film exemplifications, focusing on the artist's epiphanic landscapes and his „mythical consciousness”. The proposal to go beyond
\end{abstract}

1 Werner Herzog, urodzony jako Werner Stipetić 5 września 1942 roku w Monachium. Dorastał na farmie w górach Górnej Bawarii. Po maturze studiował historię, literaturę i teatr w Monachium oraz Pittsburghu. Przerwał studia, sam uczył się realizacji filmów. Zadebiutował w 1962 roku filmem dokumentalnym Herakles. Pełnometrażowy debiut to rok 1967 i film Znaki życia. Herzog był wielokrotnie nominowany i nagradzany podczas festiwali filmowych na całym świecie; zdobył ponad 30 nagród. Jego dorobek to ponad 60 filmów dokumentalnych i fabularnych realizowanych w najróżniejszych, egzotycznych, oddalonych częściach świata. Do najistotniejszych osiągnięć należą filmy w parze Herzog-Kinski, ale także dokumenty: Nawet karty byty kiedyś mate (1970), Lekcje ciemności (1990), Dzwony z gtębin (1993), Koto czasu (2003), Spotkania na krańcach świata (2007) czy Jaskinia zapomnianych snów (2010).

2 Werner Herzog was born Werner Stipetić on 5 September 1942 in Munich. He grew up at a farm in Upper Bavaria. Having graduated from high school, he studied history, literature and theatre in Munich and Pittsburgh but did not complete his studies. As a filmmaker, he was self-taught. His film debut was the documentary Herakles (1962). His first feature film was Signs of Life (1967). Herzog was many times nominated and awarded at film festivals worldwide; he won more than 30 awards. His oeuvre includes over 60 documentaries and feature films shot in various exotic, faraway corners of the world. Feature films made in the Herzog/Kinski collaboration are counted among the director's most important achievements, as are the documentaries: Even Dwarfs Started Small (1970), Lessons of Darkness (1990), Bells from the Deep (1993), Wheel of Time (2003), Encounters at the End of the World (2007) and Cave of Forgotten Dreams (2010). 
the observational film based on a rational paradigm is drawn precisely from the work of the last romantic Master of cinema.

Key words: Werner Herzog, epiphany, apocalyptic myths, ethnographic documentary

Autorka wyjaśnia przyczyny, dla których poszukuje filmów etnograficznych poza etnografią. O roli i statusie filmu etnograficznego pisze na podstawie trzech dokumentów Wernera Herzoga. Autorka analizuje je z perspektywy antropologicznej. Postulat reżysera o nieadekwatności współcześnie tworzonych obrazów (w tym obrazów filmowych) do stanu cywilizacji „śledzi” w filmowych egzemplifikacjach, skupiając się na epifanicznych krajobrazach artysty i na jego „mitycznej świadomości”. Propozycja wyjścia poza film obserwacyjny, bazujący na racjonalnym paradygmacie, czerpie właśnie z twórczości ostatniego romantycznego Mistrza kina.

Słowa kluczowe: Werner Herzog, epifania, mity apokaliptyczne, dokument etnograficzny

Odebrano / Received: 31.01.2020

Zaakceptowano / Accepted: 20.05.2020

Po tamtej stronie równika nic nie jest grzechem.

Fitzcarraldo

\section{Słowo poprzedzające}

W końcu lat 70.w mojej etnograficznej edukacji dotyczącej filmu dokumentalnego obowiązywała zasada: film dokumentalny o aspiracjach naukowych powinien polegać na szczegółowym opisie i wyjaśnieniu zachowań opartych na obserwacji ludzi w ich kulturowym środowisku. Celem winna być prawda, nawet wówczas gdy wiemy, że jest trudno osiągalna. Etnograf bowiem jest zobowiązany do minimalizowania wszelkich zniekształceń filmowanej rzeczywistości. Pozytywistyczny duch nauki określił na wiele lat sposób myślenia o filmie, jego statusie i roli w etnografii. Zasada weryzmu, długiej obserwacji i obiektywny, zdystansowany, nieczuły narrator filmujący po to, by wspomagać słowo pisane - były już wówczas dla mnie niewystarczającym „opowiadaczem” o innych światach. Niedawno pisałam:

W filmach aspirujących do gatunku dokumentu etnograficznego brakowało mi już wówczas „pytającego języka”, odsłonięcia tego, co dzieje się „,wewnątrz” filmowanej rzeczywistości, pierwiastka irracjonalnego - tak obecnego przecież w ludowej egzystencji, ludowej wizji świata. (...) I właśnie już w tamtych latach - mówiąc językiem filmu - nie dostrzegłam w większości produkowanych obrazów filmowych „życia drugiego planu”, żadnej „głębi ostrości”, tylko „płaskość krajobrazu”. Wieś utalentowana, świąteczna, wierna tradycji, 
rozśpiewana, wesoła. „Kto zasię smutny, strudzony, / z dziurą na łokciu i z zezem, tego najwyraźniej brak". (...) Nie wystarczała mi pieczołowicie rekonstruowana przeszłość. W nauce $\mathrm{i}$ w filmie ważna była dla mnie namiętność poznania i odnajdywania prawd uniwersalnych ${ }^{3}$.

Prawda miała wypływać ze źródłowego doświadczenia twórcy, egzystencjalnego przeżycia, które próbuje budować uogólnienia, nawet bez mimetycznej dbałości o detale. $\mathrm{Z}$ tych to przyczyn zaczęłam poszukiwać filmów etnograficznych poza etnografią, by użyć frazy Zbigniewa Benedyktowicza ${ }^{4}$.

Jedną z pierwszych moich fascynacji były dokumentalne obrazy Wernera Herzogakreacyjne, osobiste, hipnotyczne, a także radykalna Deklaracja z Minnesoty jego autorstwa z 30 kwietnia 1999 roku. To jedyny teoretyczny tekst Herzoga poświęcony problemom prawdy w kinie. Pierwszy punkt mówi: „tak zwane cinèma vérité zostało pozbawione vérité (prawdy). Dociera ono jedynie do prawdy powierzchownej, prawdy księgowych”. I dalej, w punkcie piątym: „w kinie występują głębsze pokłady prawdy. Istnieje coś takiego jak prawda poetycka i ekstatyczna. Jest tajemnicza i ulotna, a uchwycić ją można tylko poprzez zmyślenie, wyobraźnię i stylizację"5.

W Deklaracji z Minnesoty Herzog wprowadza rozróżnienie między faktem a prawdą. Fakty dotykają li tylko powierzchni zjawisk, prawda jest sprawą iluminacji. Prawda poetycka nie jest prawdą rejestracji, ,jest prawdą aleteiczną, prawdą "wy-dobywającą» ku nieskrytości wszystko to, co do tej pory zostało ukryte, co samo jeszcze nie wyistoczyło się w indywidualnie istniejącą rzecz, czego nie można w ogóle dostrzec w porządku rejestracji”.

Dokumenty Herzoga zarzucają wartości referencyjne będące paradygmatem dokumentalizmu na rzecz kreacji: inscenizacji, reżyserii dialogów i monologów, niejednokrotnie jawnie nieautentycznych, oraz wielkiego radykalizmu estetycznego. Jego twórczość egzystująca poza czystością gatunkową dziś przez niektórych krytyków nazywana jest filmowym traktatem filozoficznym ${ }^{7}$. Egzegeci ciągle tworzonego i dopełnianego eseju o człowieku podają tej twórczości trzy źródła: niemiecki romantyzm (Novalis, Friedrich, Hoffmann), niemiecki nurt filozofii egzystencjalnej (Schopenhauer, Nietzsche, Steiner) i niemiecki ekspresjonizm filmowy (Murnau) ${ }^{8}$.

3 Nowina-Sroczyńska (Dokument kreacyjny. Przeciw bierności poznawczej i minimalizmowi formy, artykuł w druku, „Konteksty. Polska Sztuka Ludowa”, 2020). Cytuję w nim fragment wiersza Wisławy Szymborskiej Miniatura średniowieczna, zob. Szymborska 2010, s. 219.

${ }^{4}$ Jest to słynna fraza Zbigniewa Benedyktowicza, którą posługuje się w swoich wystąpieniach publicznych, podczas konferencji naukowych.

5 Herzog 2010, s. 112.

6 Majmurek 2010, s. 140.

7 Zob. Uszyński 1986, s. 179.

8 Sarbiewska 2014, s. 10-14. 
Kino Wernera Herzoga nazwano kiedyś „kinem w podróży”. Realizuje filmy „na granicach ludzkiej ekumeny"10: w australijskim buszu, na lodowej Antarktydzie, na Saharze, u wybrzeży Afryki Wschodniej, w Gujanie Brytyjskiej, w Indiach. Penetruje głębię ziemi i oceanów. Zjawia się w lasach tropikalnych, nad rzekami i przy wodospadach, w środku gór - poszerzając nam, widzom, przestrzeń świata ${ }^{11}$.

Krytycy jego filmowej twórczości wiele myśli poświęcili naturze, bo Herzog nadaje jej niezwykły status. Nader często analizowano obecną w jego filmach dychotomię Natura / Cywilizacja, gdzie ta pierwsza pokonuje drugą, pochłaniając ją i tworząc obrazy apokaliptyczne. To właśnie pejzaże stają się dla reżysera źródłem filmowej opowieści: „znajduję jakiś pejzaż i opowiadam historię"12. On i jego ekipa - przyjdzie mi do tego powrócić - realizując filmy, wiele ryzykują.

Bohaterowie filmów Herzoga to ludzie skrzywdzeni, odrzuceni - odmieńcy, pasjonaci i szaleńcy. Jego filmy przekonują widza, że przeciętni reprezentanci kultury istnieją w sposób nieautentyczny, powielają obiegowe stereotypy myślenia i kierują się przyjętą przez społeczeństwo normą racjonalności. Zderzenie z cywilizacją jest ważnym kontrapunktem twórczości Herzoga; ujawnia, że to właśnie odmieńcy, pasjonaci i szaleńcy istnieją autentycznie ${ }^{13}$. Obcy w świecie, wydziedziczony z życia jak Kaspar Hauser, człowiek $\mathrm{z}$ innej planety, który obserwując lokalnych mieszczan, zaczyna zadawać pytania, a nawet kwestionuje zachowania innych. Jak się dokładnie przyjrzymy - mówi Herzog - to zauważymy, ze wszyscy wokół są ekscentrykami, „a jedynym człowiekiem, który nadaje rzeczywistości jakiś sens i który nas porusza, jest właśnie Kaspar Hauser"14.

Maria Janion, admiratorka twórczości artysty, w jednym z wywiadów konkluduje: „Zawsze niesentymentalnie był po stronie poniżonych, skrzywdzonych i takich, którzy żyjąc, nigdy się nie urodzili”" ${ }^{15}$. Herzog wyznał kiedyś, że jego bohaterowie pozbawieni są cieni: „Przychodzą z ciemności, a przecież tacy ludzie nie mogą mieć cieni. Światło ich zabija. Przez moment są tutaj, a potem wracają w ciemność”"16.

Moja antropologiczna opowieść jest pokłosiem podróży z Herzogiem po trzech oddalonych rejonach. Rezultatem są filmy dokumentalne, ale niech czytelnika i widza nie prowadzi nadmierne przywiązanie do przezroczystości narratora - oczywistego paradygmatu dokumentalizmu. Werner Herzog: „Czysta racjonalność pasuje do filmu równie mało jak do muzyki. Tak się nie da, muzyki nie można racjonalnie zorganizować.

\footnotetext{
${ }^{9}$ Słodowski 1994, s. 75.

${ }^{10}$ Czaja 2013, s. 323.

${ }^{11}$ Zob. Nowina-Sroczyńska 2015, s. 572.

${ }^{12}$ Seel, Zmudzinski 1994, s. 24.

${ }_{13}$ Zob. Sarbiewska 2014, s. 59.

${ }^{14}$ Pflaum 2010, s. 13.

${ }^{15}$ Szczuka 2010, s. 94.

16 Bochmann 1994, s. 52.
} 
Kiedy komponuje pan muzykę, ona przychodzi skądinąd. I to jest też podglebie dla filmu"17.

Przypomnijmy jeszcze dla porządku: Herzog zaciera podziały między gatunkami (wyjątek stanowi film Nosferatu wampir) i jest w tym oszustem doskonałym ${ }^{18}$. Realizując film, zawsze stawia rzeczywistości pytanie i uzyskuje odpowiedź.

Portret intelektualny Herzoga - mówi Artur Żmijewski - na różne sposoby przenika do dokumentu i przyjmuje najrozmaitsze formy - od popularnej jak programy Discovery po wyrafinowane narzędzia analityczne, a ambicją jest poznanie rzeczywistości z pomocą obrazu ${ }^{19}$.

\section{Koło czasu (ze specjalnym udziałem Jego Świątobliwości XIV Dalaj Lamy)}

Styczeń 2002. Werner Herzog przybywa do Indii, do doliny Gangesu, bo tam właśnie odbywa się jedno z najważniejszych świąt buddyzmu - inicjacja Kalaczakry. Od pierwszych scen filmu mamy do czynienia $z$ autorską narracją. Reżyser wyjaśnia spoza kadru, że tutaj właśnie, w pobliżu wsi Bodh Gaya, dwa i pół tysiąca lat temu przybył książę Siddharta Gautama, opuściwszy swój dom u podnóża Himalajów. Podróżował, by poznać prawdę. Znalazłszy drzewo, długo pod nim modlił się, medytował. Doznał oświecenia. Nazwano go Buddą.

Początkowe kadry ukazują panoramę doliny Gangesu, „opisująa krajobraz nizinny porosły nikłą przedwiosenną trawą; w tle sylwetki pracujących nad rzeką ludzi. Z ekranu emanuje spokój. Narrator: „gdy przybył, zobaczył pewnie coś w tym rodzaju”. Tym komentarzem Herzog nie tylko interpretuje obrazowaną rzeczywistość, ale także ją konstruuje, demiurgicznie dokonuje „paraliżu” czasu. Ustanawia, że to, co zdarzyło się tutaj in illo tempore, może dziać się nadal dzięki reaktualizacji czasu przez obrzędy, rytuały, mity i ofiary. Jesteśmy w Eliadowskim „wiecznym teraz”.

Wiemy już, że obecność komentarza nie odsyła nas do gatunku edukacyjnego, tym bardziej że komentarz będzie się urywał; wiele pielgrzymich działań i rytuałów pozostanie bez wyjaśnienia. Co dwa, trzy lata - komentuje Herzog - na wezwanie Dalaj Lamy pielgrzymi przybywają, by znaleźć się w cieniu drzewa (które jest piątym pokoleniem drzewa pierwotnego), by mieć udział w źródłach mocy. Kalaczakra to koło czasu, złożony rytuał inicjacyjny mający na celu obudzenie będącego w każdej żywej istocie ziarna oświecenia. $Z$ pomocą uważnej kamery Herzoga obserwujemy przybywających pielgrzymów z: Tajlandii, Tybetu, Mongolii, Sri Lanki, Bhutanu. Czerwień chust, kolor ochry mnisich szat; w scenach obserwacji tych, którzy przybyli - przewaga koloru pomarańczy. Jesteśmy pośród nich, rozstępują się przed filmową ekipą; jedni zauważają obcych, drudzy ich ignorują. I nagle kamera odwraca się, żeby zatrzymać się na twarzy

${ }_{17}$ Pflaum 2010, s. 15.

${ }^{18}$ Zob. Czaja, Juszczak 2017, s. 66-70.

${ }^{19}$ Wypowiedź A. Żmijewskiego w: Majmurek, Wiśniewska, 2010, s. 167. 
jakiegoś mężczyzny. Obserwuje go, „myśli”. To jest moment, w którym artysta czeka na odpowiedź rzeczywistości. Tym razem - bez odpowiedzi. Kolejne sceny nadal mają walor introdukcji. Herzog rozmawia z XIV Dalaj Lamą. Ten wyjaśnia, że kulminacyjnym punktem święta jest uczestnictwo przy tworzeniu mandali przedstawiającej koło czasu; mandala jest postrzegana jako siedziba Buddy i ponad siedmiuset świętości. To rodzaj malowidła, którego wizualizacja uzmysławia medytację nad pojęciem pustki. Gdy duch nasz stopi się z pojęciem pustki lub ostatecznej natury rzeczy, mandala przeradza się w świat fizyczny.

Święto Kalaczakry trwa dziesięć dni i obejmuje nauki, filozoficzne i teologiczne dysputy, modlitwę i konstrukcję mandali. Herzog cofa się poza krąg świętości. W długich scenach obserwujemy trudy pielgrzymiej podróży. Wielu z nich przemierza drogę w „trójdzielnych pokłonach” (wzniesione i złożone nad głową ręce, dotknięcie okolic serca złożonymi dłońmi, przyklęknięcie i położenie ciała tak, by dotknąć czołem ziemi). Długie ujęcia ludzi dotykających ciałem ziemi, kamienistej, nierównej, zabłoconej - ich trud ustanawia świętość drogi. Herzog rozmawia z mnichem tybetańskim, który trzy lata szedł w ten właśnie sposób. Na kostkach dłoni ma narośle; przeżył ból, głód, pragnienie. Niejednokrotnie napotykani ludzie pomagali mu. Gdy doszedł do świątyni i zobaczył drzewo oświecenia, osiągnął spokój. Reżyser pyta mnicha o sens tej drogi; pada prosta odpowiedź: „Wiem, jak duża jest ziemia, zmierzyłem ją własnym ciałem”.

Kamera - u Herzoga zawsze narzędzie poznania - śledzi rytuały wokół mandali. Wyznaczony kwadrat platformy nad baldachimem, na nim będzie powstawać konstruowany z piasku obraz buddyjskiej kosmografii. Inicjującym rytuałem jest poświęcenie powierzchni, na której powstanie obraz; mnisi gromadzą się wokół, hałas dzwonków, szum modlitw i niezwykły taniec wokół świętego miejsca, gdzie tańczący zawieszają ruchy, by po chwili go wznowić.

Pojawiają się kłopoty - rozpoczęcie układania mandali należy do Dalaj Lamy. To on prowadzi inicjację - modlitwy, nauki, medytacje. Anno Domini 2002 Dalaj Lama jest nieobecny, zachorował. Rytuał rozpoczęcia inaugurują inni ważni hierarchowie.

Kamera obserwuje mnichów w skupieniu sypiących z piasku „koło czasu”. Jest ich ośmiu, wymieniają się, gdy są zmęczeni, a pracują od szóstej rano do północy.

Poznajemy wiele innych przestrzeni wokół świętego drzewa, świątyni i mandali. Kolumnę, która - jak wierzą pielgrzymi - po dotknięciu ma moc uzdrawiającą bolące części ciała: plecy, głowę, piersi. Pielgrzymi zataczają kręgi. Wiele tu epifanii koła, tej najdoskonalszej figury, co do której wiemy, że niczego nie ma przed ani poza, niczego większego ani mniejszego, wszystkie jego punkty są jednakowo oddalone od centrum. Bez początku i końca, na kształt wieczności, kulisty ruch Kosmosu, wiecznie odnawiający się rytm życia. Koło (mandala) to przecież najwyższy punkt oświecenia. Ta ciągłość cykli wiedzie ku nieskończoności i pełni. Należy dodać, że przestrzeń sacrosfery, w której egzystują pielgrzymi, ustanawiana przez kolejne „wcielenia” okręgu (taniec, mandala, kolumna, drzewo) zmienia zawsze status tych, którzy znajdują się wewnątrz granic 
określonych przez okręgi. Tworzy się „skosmizowana enklawa” - miejsce bezpośredniego uczestnictwa $\mathrm{w}$ sacrum $^{20}$. Symbol niezwykle multiwalentny, $\mathrm{w}$ aspekcie znaczeniowym złożony. Koło to nie tylko symbol solarny, to tajemnica wiecznej cykliczności. Uczeni podkreślają dwoistość struktury koła: ruch obrotowy i bezruch, obwód koła i jego środek. „W swej części zewnętrznej koło ukazuje fazy przebiegu czasowego, środek - bezruch i paraliż czasu"21. Być może w tańcu okrążającym mandalę u początku jej tworzenia mnisi unaoczniają strukturę koła - jego niezbywalną dwoistość.

Werner Herzog buduje topografię miejsca świętego bardzo starannie. Gdy oddalamy się od źródeł mocy, uzyskujemy dystans, także do świętości, i obserwujemy działania w sferze profanum: gotowanie jedzenia dla pielgrzymów, niezwykłą precyzję w produkcji klusek wrzucanych do wrzątku, co dzięki pracy kamery przypomina niezwykły taniec. Młode kobiety czyszczą maślane lampki, które mają pomóc w uzyskaniu oczyszczenia i oświecenia; pojawiają się sceny z dziećmi, które bez skrępowania patrzą w oko obiektywu. A samotne dziecko na małym placu nieopodal świętego drzewa niezdarnie powtarza pokłony dorosłych; obserwujemy rozdawanie pielgrzymom zupy oraz jarmarczną małpkę, która podskakuje w takt bębenka, niosąc radość dzieciom.

Reżyser zagląda też do strefy nauki; na wolnym powietrzu mnisi biorą udział w naukowej debacie. Jeden z uczonych - to wyjaśnia nam narrator - broni dysertacji z filozofii buddyjskiej. Spór prowadzony jest w „stylu tybetańskim” i dotyczy dwóch aspektów rzeczywistości - naszego życia codziennego i pojęcia pustki, która zgodnie z nauką Buddy jest rzeczywistością ostateczną. Niektórzy stoją, inni biorą udział w dyskusji, siedząc. Jest i protagonista. Obserwujemy napięcie i ekscytację uczonych, musi nam wystarczyć obraz, nie rozumiemy istoty sporu. $Z$ przerwą na obiad będą debatować przez noc, do świtu.

Maj 2002. Werner Herzog przenosi się do Zachodniego Tybetu. Powodem - święta góra Kailash, epifania środka świata dla wyznawców buddyzmu, hinduizmu i religii Bon, której wyznawcy czcili górę na długo przed pojawieniem się buddyzmu. Ta dziwna, rozbijająca strukturę filmu wyprawa motywowana jest przez Herzoga: mandala i góra Kailash to dla wiernych symboliczne siedziby Buddy.

Śnieżny Diament, góra sięgająca nieba, bezbrzeżnie piękna, wznosi się w pobliżu jeziora, które jest żeńską towarzyszką świętego wzniesienia. Razem tworzą znaną z wielu religijnych spekulacji przestrzeń mitycznej geografii. Joseph Campbell ukazuje górę Fudżi odbijającą się o świcie w towarzyszącym górze jeziorze Yamanaka ${ }^{22}$. Ten dwumian jest częstym składnikiem morfologii kulturowej wielu miejsc świętych ${ }^{23}$. Herzoga zafascynowała Kailash także ze względu na jej obecność w centrum wizualiuzowanej mandali, którą oglądaliśmy w Indiach w czasie Kalaczakry.

\footnotetext{
${ }^{20}$ Zob. Kowalski 2007, s. 231; Forstner 1990, s. 57-58.

${ }^{21}$ Cirlot 2000, s. 191.

${ }_{22}$ Zob. Campbell 2004, s. 314.

${ }^{23}$ Zob. Eliade 2009, s. 71.
} 
W maju, w pełni księżyca, w Roku Konia, przybywają tu rzesze pielgrzymów; ponownie w długich ujęciach artysta skupia się na trudach drogi. Przepełnione ciężarówki, strudzone kobiety i dzieci docierają do stóp góry, gdzie spędzą jakiś czas, śpiąc na ziemi bądź- komentuje reżyser - w namiotach, co jest komfortem wielu pielgrzymów. Powstaje miasteczko otoczone wieloma pielgrzymimi ciężarówkami, które w tym ascetycznym krajobrazie zdają się cyrkowo-jarmarczną przestrzenią. Święto dzieli się na dwa zespoły rytuałów. Kamera obserwuje dokładnie każdy z nich; te partie filmu odnoszą się do stylu kina obserwacyjnego. Pierwszy zespół to wspólne budowanie masztu (mam wrażenie, że to epifania kosmicznego słupa; Herzog tego nie wyjaśnia). Drugi - to inicjacyjna w swym charakterze droga okrążająca górę. Trudna, bo 52-kilometrowa na średniej wysokości 5000 m n.p.m. (przełęcz najtrudniejsza do przejścia znajduje się na wysokości 5600 m n.p.m.). Nie wszyscy docierają do celu. Niektórzy - informuje artysta - umrą, nie mieli bowiem czasu na aklimatyzację. Wszyscy idą zgodnie ze wskazówkami zegara, jedynie opacznie - wyznawcy Bon - dla zaakcentowania swej odmienności (i zapewne największego prawa do sacrosfery). Już bez komentarza kamera obserwuje drogę wokół góry; ponownie hipnotyczne kadry, ludzie maleńcy wobec niebotycznego masywu góry. Ten akcent, w moim przekonaniu, jest kolejną manifestacją stosunku Herzoga do natury - pięknej, ale obojętnej, etycznie neutralnej, tkwiącej w bezruchu i wiecznej. Pielgrzymi trud ma odganiać złe myśli, a moc góry i ofiara drogi wyzwalają od złej karmy. Krajobraz statycznej góry i mieniącego się światłem jeziora kończy wyprawę Herzoga do Tybetu.

Styczeń 2002. Wracamy do mnichów układających z barwnego piasku mandalę. Herzog ponownie spotyka się z Dalaj Lamą. Pyta o górę Kailash: Czy jest środkiem świata? Odpowiedź nie jest zadowalająca. Jego Świątobliwość mówi o wielości środków: osad, miast, rejonów, ale „tak naprawdę to ja, to pan jest środkiem świata”. Kamera obserwuje działania wokół świętego drzewa. Zatrzymuje się przy mnichu, który kupił od sprzedawcy małe ptaszki uwięzione w klatce. Kamera uważnie obserwuje mnicha; ten zamyka ptaszki w dłoni. Modli się? Medytuje? Czy tylko milczy? Po chwili wypuszcza je. Zapytany, dlaczego to zrobił, klarownie, spokojnie odpowiada: „Wszystkie osoby są równe, każdy może być Buddą, ale żeby być oświeconym, trzeba być wolnym”. Sceny te obserwują dzieci i młodzi mnisi, obserwujemy również my, widzowie. Znamy kłamstwa Herzoga, może to tylko słowa artysty, które na jego prośbę mnich wypowiedział do kamery. A może realność, która nie pierwszy raz odpowiada na pytania, które stawia jej reżyser - intensywnie, mądrze, pięknie.

Modlitwy młodych mnichów, inni przygotowują już dary dla pielgrzymów, te są dla nich niezwykle cenne - osobliwe kulki z mąki przynoszące długie życie. Rozdawane z koszy, rzucane pośród pielgrzymów powodują niespotykany dotąd tumult, chaos, rywalizację.

Powoli zbliżamy się do kulminacji rytualnej. Mandala jest gotowa. By pielgrzymi jej nie zniszczyli (nawet oddechem), osłania się ją ekranami z pleksiglasu. Teraz można w spokoju, dotykając szyby, okrążyć mandalę, milcząc lub modląc się. 
Wszyscy czekają na Jego Świątobliwość, który powinien poprowadzić inicjację. Ogłoszono, że mimo choroby przybędzie. Już od trzeciej nad ranem karnie ustawiają się pielgrzymi, by znaleźć się jak najbliżej Dalaj Lamy. Słyszymy modlitwy, powtarzający się rytm słów, których nie rozumiemy, brzmiący jak niezwykła egzotyczna muzyka. I kolejne hipnotyczne sceny: pielgrzymi, którzy siedzą oddaleni, by być bliżej i pełniej uczestniczyć w świętości, rzucają szale modlitewne przed scenę, na której zasiądzie prowadzący inicjację. Wkrótce przed Dalaj Lamą wyrastają stosy białych pielgrzymich szali. Wielu jest bliżej, prawie na wyciągnięcie ręki. Herzog obserwuje poprzez długie ujęcia tak ważną w wielu kulturach religijnych „transmisję” świętości, nasycanie się nią poprzez bliskość, dotyk - najważniejsze sensorium uczestnictwa w sacrum.

Następuje punkt kulminacyjny. Długo obserwujemy twarz XIV Dalaj Lamy, jego zakłopotanie i cichą modlitwę. Nie będzie mógł przewodniczyć inicjacji. Wielość rytuałów, zbyt intensywna duchowa obecność nie pozwala na to choremu. Pielgrzymi milkną, w ciszy będą modlić się za zdrowie Jego Świątobliwości przez następną noc. Herzog informuje, że obchody inicjacyjne przeniesione zostaną do Grazu w Austrii, gdzie bardzo sprawnie działa wspólnota buddyjska.

Październik 2002, Graz. Artysta wyjaśnia, że Dalaj Lama rzadko zgadza się na organizowanie jednego $\mathrm{z}$ najważniejszych świąt świata buddyjskiego na Zachodzie. Ciekawa jest motywacja - z dużą ostrożnością odnosi się do konwersji, szczególnie jeżeli przedsiębrana jest przez ludzi „odległych kulturowo”; z drugiej strony, uważa, że wolność wyboru i równość wyznań są istotniejsze.

Rytuały Kalaczakry odbywają się w olbrzymiej hali mieszczącej 8000 osób; scena $\mathrm{z}$ telebimem, obok - miejsce dla powstania mandali. Więcej ludzi Zachodu, nieco mniej mnichów z odległych buddyjskich obszarów. Mnisi konstruują mandalę z piasku, czemu towarzyszą modlitwy i medytacje. Ważny moment inaugurujący: Dalaj Lama w towarzystwie innych mnichów wyznacza linie podziału i orientuje centrum.

Spotykamy pośród mnichów modlących się najbliżej tronu Jego Świątobliwości człowieka świeckiego, więźnia politycznego; po raz pierwszy zobaczy Dalaj Lamę, w więzieniu spędził 37 lat. Ciągle trwają medytacje i modlitwy. Gdy zakończy się układanie mandali i zostanie osłonięta, obserwujemy rytuały wróżebne mające na celu profetyczne potwierdzenie (bądź zaprzeczenie) powodzenia inicjacji.

Teraz następują wielogodzinne nauki, medytacje i modlitwy. Jednym z ostatnich aktów, niezwykle istotnym po intensywnych medytacjach, jest zasłonięcie oczu - czynią to wszyscy pielgrzymi. Czerwone opaski zakrywają oczy wielu uczestników rytuału, inni medytują już z odsłoniętymi oczami. Czyżby już doznali duchowej przemiany? I kolejne długie ujęcia medytujących duchownych i świeckich pielgrzymów egzystujących w ciszy i skupieniu. Modlą się tak długo - mówi nam Herzog - aż zostaną wprowadzeni na wyższy poziom świadomości. Rytm modlitw, Dalaj Lama powtarza (towarzyszy temu niezwykły taniec rąk) kilka niezrozumiałych dla widza słów. Kamera długo obserwuje 
medytacje, zbliżenia twarzy, portrety ogólne pielgrzymów, „szum” modlitw. Teraz Herzog informuje widza: „i tu nastąpił niewidoczny dla kamery moment duchowego odrodzenia”.

Uczestniczymy w zniszczeniu mandali, następuje powolny proces jej dekonstrukcji - najpierw mnisi niszczą fragmenty od granic do centrum, potem młodzi szczoteczkami gromadzą piasek w jedno miejsce. XIV Dalaj Lama zbiera mandalę do konchy. Inicjacja ma nie tylko zbudować osobę „społeczną”, nadać jej inne prawa i obowiązki, ale także - jak chcieli tego Gerardus van der Leeuw ${ }^{24}$ i Mircea Eliade - zmienić ontologię wewnętrzną każdego człowieka poddanego rytuałom inicjacyjnym. Buddyjska mandala unaocznia drogę do centrum, pomaga, ale pielgrzym pośród innych pielgrzymów pozostaje sam ze swoim mistrzem. Herzog opowiada o trudach realnej drogi i trudach podróży wewnętrznych. Akt końcowy: znajdujemy się nad rzeką w Grazu; w towarzystwie pielgrzymów, mnichów, przygodnych widzów Dalaj Lama błogosławi wiernych i wysypuje piasek mandali $z$ konchy do rzeki.

Pielgrzymi rozumieją, że mandala symbolicznie odsyła także do nietrwałości rzeczy stworzonych. Nawet tych pięknych, w których zawarto ponad siedemset świętości. Jej przesłanie dotrze do wielu miejsc. W następnych kadrach już tylko prawie pusta hala, niewielu skupionych pielgrzymów, służby porządkowe i pracownik ochrony.

Styczeń 2002, powrót do Indii. Panorama poprzez puste pielgrzymie poduszki (400 tysięcy), w zasadzie wszyscy odjechali po niedokończonym rytuale Kalaczakry. I choć niewiele uwagi krytycy poświęcili temu filmowi, to tę scenę przypomina kilku: „Buddyjskie święto Kalaczakry; kiedy hałaśliwy tłum wiernych opuścił już miejsce rytuałów, Herzog znalazł jednego medytującego mnicha. Film wycisza się, a reżyser zastanawia się, co jest zgodne $\mathrm{z}$ wierzeniami buddyjskimi, czy ów mnich stanowi właśnie centrum świata" 25 .

Tę myśl nazywa Herzog w komentarzu finalną i „zwierzęcą”. Pyta bowiem najpierw: Czy doznał oświecenia? Czy modli się za nas? Widzimy go z dalekiej odległości, kamera powoli zbliża się - on siedzi pośród porzuconych poduszek, kolejne zbliżenie wewnętrzy spokój i modlitwa mnicha. I to wtedy Herzog zadaje pytania. Ostatni kadr filmu, kamera powraca jak myśl do Tybetu i świętej góry - przegląda się ona w mieniącym się jeziorze.

Ma rację Aldona Kopkiewicz, gdy pisze o obrazach modlącego się mnicha, które przechodzą w kosmiczny pejzaż: „Następuje tu zerwanie ciągłości i propozycja medytacji przedstawiającej jezioro i niebo przenikające się z niewyraźną, migotliwą linią horyzontu. Pejzaż (...) metaforyzuje pustkę i robi to w buddyjski sposób”26. Termin „pustka” w tym kontekście wskazuje oczywiście na coś poza zwykłym znaczeniem „pustki” jako przeciwieństwem „pełni”.

\footnotetext{
${ }^{24}$ Zob.van der Leeuw 1997.

${ }^{25}$ Kopkiewicz 2010, s. 40.

${ }^{26}$ Kopkiewicz 2010.
} 
Pustka (Siunjata) nie oznacza względności, „zjawiskowości” czy „nicości”, lecz raczej Absolut lub coś, co posiada charakter transcendentny. (...) Kiedy buddyści głoszą, że wszystkie rzeczy są puste, nie oznacza to, że są oni zwolennikami nihilistycznego punktu widzenia; przeciwnie, mówi się tu o tej ostatecznej rzeczywistości, której nie można podciągnąć pod kategorie logiki. (...) Dlatego najlepszym określeniem Siunjaty jest Absolut ${ }^{27}$.

Zastanawiam się, czy film, który postarałam się w miarę dokładnie przedstawiće ${ }^{28}$, mógłby być w szerokim etnograficznym środowisku postrzegany jako etnograficzny dokument? Egzegeci kina Herzoga są zgodni, że jego twórczość należy do struktur otwartych (koncepcja „dzieła otwartego” Umberto Eco), to znaczy takiego, którego utwory nie mają z góry określonych kształtów i znaczeń, a zyskują je dopiero w trakcie wykonania, oglądania, lektury; nie mają jednego wykładnika znaczeniowego. Dzieło Herzoga może być wyjaśnione w kategoriach etnograficznych, socjologicznych, metafizycznych, historiozoficznych. W polskich dokumentach etnograficznych prezentujących religijność skupiano się na działaniach rytualnych, obrzędowych, stojąc na zewnętrz nich. Tymczasem Gerardus van der Leeuw przekonuje, że w religiach:

Wszystko, co zewnętrzne, sprowadza się do tego, co wewnętrzne, i na odwrót: nie ma tego, co wewnętrzne, bez tego, co zewnętrzne, a gdyby było, nie mogłoby się ujawnić. Święty kamień, Bóg, sakrament są przeżyciami dokładnie tak samo jak obawa, miłość, pobożność. $\mathrm{W}$ obu przypadkach nie chodzi o to, co się ukazuje, co się pojawia w znaku. Uczucie nie istnieje bez mowy lub mimiki; myśl - bez formy, działania; nawet mistyka wymaga słów ${ }^{29}$.

Wydaje się, że nie zrozumiem przeżycia religijnego, jeżeli będę zawierzała tylko zdarzeniom zewnętrznym:

Zdarzenie i przeżycie są tą samą rzeczą - raz jako fakt, raz jako sens. Zjawisko, fenomen jest zatem zawsze związany z przeżyciem, w przeciwnym bowiem wypadku nie mógłby nam się jawić jako sens. (...) Przeżyciem religijnym jest takie przeżycie, którego sens odnosi się do całości. Nigdy nie daje się ono zrozumieć na podstawie momentu, lecz zawsze z punktu widzenia wieczności. Jego sens jest ostateczny. (...) Przeżycie to ma charakter eschatologiczny, wskazuje na coś poza sobą. Oznacza dla człowieka to, co ostateczne, granicę. Nie mogłoby jednak tego znaczenia uzyskać, gdyby nie było początkiem, tym, co pierwsze. Jego sens przeżywa się jako całkiem inny, jego istotę jako objawienie ${ }^{30}$.

${ }^{27}$ Campbell 2004, s. 315.

${ }^{28}$ Koto czasu (2003) jest filmem trudno dostępnym; osiemdziesięciominutowy czas projekcji predestynował obraz do rozpowszechniania w kinach, choćby studyjnych. W Polsce pokazywany jedynie w trakcie tematycznych spotkań, przeglądów i festiwali.

${ }^{29}$ van der Leeuw 1997, s. 398.

${ }^{30}$ van der Leeuw 1997, s. 401. 
W kinie „otwartym” można zacierać granice między wypowiedzią dokumentalisty i onirycznego kreatora, który eksplikując linearny czas rzeczywistości filmowanej, jest zdolny przekształcić go w „wieczne teraz” lub w świat „poza czasem” po to, by „tchnąć weń uniwersalną prawdę"31. Dzieło Herzoga ma wymiar poznawczy; ważne jest towarzyszenie rytuałom, ważna jest naoczna wiedza tym rytuałom towarzysząca. Obecność w miejscu wydarzenia filmowanego przez Wernera Herzoga jest już refleksją na temat wydarzenia. Ma rację Artur Żmijewski, gdy mówi, że w dokumentach Herzoga obecność jest zawsze namysłem, sposobem analizy. Sfilmować równa się zdobyć. Obraz to czyste dane ${ }^{32}$.

I problem drugi, równie dla mnie ważny. Otóż - artysta nam to zapewnia - można szukać sposobów przełożenia na język filmu technik medytacyjnych, przeżyć drogi, przeżyć religijnych. Warunkiem wydaje się przekroczenie własnej kondycji i przywłaszczenie sobie nadprzyrodzonej mocy tworzenia ${ }^{33}$. Maria Janion uznała Herzoga za wiecznego transgresora. Do problemu transgresji powrócę jeszcze w finalnych konkluzjach.

W Kole czasu obserwujemy inny filmowy znak twórczości reżysera - koegzystencję opozycji, niepohamowany kreacjonizm połączony z rygorystycznymi metodami dokumentalnymi ${ }^{34}$. Koto czasu to film niezwykle sensualny, angażujący wiele zmysłów. Herzog stosuje różne techniki synestezyjne, na przykład tak zwane barwne słyszenie ${ }^{35}$ - odmianę synestezji polegająca na przedstawieniu dźwięków określonymi barwami. Długie ujęcia medytujących mnichów epatujące dość jednolitymi kolorami ochry i mocnej czerwieni ich szat oraz cisza medytacji i wewnętrznych modlitw. W scenach „działań świeckich” (jedzenie, składanie namiotów, przechodzenie między sektorami) tłum jest wielobarwny jak muzyka osiągająca wymiar kakofonii. Wielokrotnie odniosłam wrażenie, że nie tylko widzę, ale czuje zapach maślanych lampek, mlecznej herbaty gotowanej w kotłach. Nie wiem, czy Herzog działa intuicyjnie, czy też dzięki synestezji pragnie osiągnąć totalne uwiarygodnienie zdarzeń tu i teraz. Kilkakrotnie stosuje zabiegi stylistyczne polegające na przypisywaniu wrażeń jednego zmysłu - innemu. W początkowych partiach filmu obserwujemy trudy podróży szczególnie tych pielgrzymów, którzy przebywają drogę, „bijąc” pokłony. Powtarzalność trzykrotnych gestów, ułożenie ciała na ziemi i dotknięcie głową, nieraz niefortunne, odczuwamy my - widzowie - Herzog chce zawładnąć naszymi zmysłami. Synestezja to tak naprawdę typ metafory występujący w poezji symbolicznej, tak więc to zdecydowana próba przekroczenia reguł klasycznego dokumentu.

\footnotetext{
${ }^{31}$ Słodowski 1994, s. 73.

${ }^{32}$ Zob. Majmurek, Wiśniewska 2010, s. 170.

${ }_{33}$ Zob. Czapliński 1994, s. 70-71.

${ }^{34}$ Zob. Czapliński 1994, s. 70.

${ }^{35}$ Zob. Stownik terminów literackich 2004.
} 
Werner Herzog to twórca sugestywny; ma szczególny sposób oddziaływania na odbiorcę. Robi to nie za pośrednictwem treści, ale przede wszystkim - tworzonych obrazów. W tej materii zbliża się do literackich symbolistów, którzy poprzez wieloznaczność natury symbolu i obrazu właśnie byli pewni, że zadaniem artysty jest sugerowanie pewnych idei, bez mówienia wprost.

I problem ostatni, który podniósł Artur Żmijewski w jednej z rozmów o twórczości Herzoga. Uznał on - dość prowokacyjnie - że reżyser w dość oczywisty sposób profanuje dokument:

Te wszystkie niekończące się panoramy, przejazdy po jakichś pustynnych miasteczkach (...) to filmowy brud. Ale Herzog konsekwentnie używa takich filmowych śmieci, profanując kino, profanując dokument. (...) Herzog uprawomocnia nielegalne narzędzia filmowe, używa filmowych brudów, które są u niego równie ważne jak wystudiowane kadry. (...) Ta nuda u Herzoga to $\mathrm{w}$ istocie rzeczy rodzaj nadwzroczności - nadmiaru widzenia. W tych długich panoramach ujawnia się jego metoda - te panoramy to sposób, w jaki się on rozgląda. Mówić ma obraz, ma grać jego informacyjne bogactwo ${ }^{36}$.

Informacyjne bogactwo obrazów Herzoga: twarze mnichów konstruujących mandalę, obserwacja Dalaj Lamy, który ma odwołać inicjację, rytuały okrążania drzewa Buddy, sceny z szalami modlitewnymi i jedna z najpiękniejszych, gdzie informację musimy sami „wyjaçc" z powtarzanych obrazów. Te powtórzenia dotyczą gorliwości młodziutkich mnichów, którzy wyposażeni w aluminiowe dzbanki i czajniczki biegną (ile starczy sił), by zdobyć herbatę dla starszych mnichów. W tym szybkim, wzmocnionym gorliwością biegu po herbatę i oddaniu jej mistrzom tkwi właśnie bogactwo informacji: czym jest mistrzostwo, autorytet wiedzy i wieku, jak cenna może być wiedza, którą mnisi otrzymują, i czym jest hierarchia w tym świętym świecie.

I scena ostatnia - mnich, który pozostał. Czy doznał objawienia? Czym jest dojście do pustki? Herzog kończy film kosmicznym pejzażem, wraca do źródeł obrazów nieświadomych, pierwszych, in illo tempore. Kiedyś mówił krytykom, że marzy o pejzażu „przekształcającym się w coś, co nie było przedtem widziane” ${ }^{37}$.

\section{Niepokorne geografie}

W 1976 roku Werner Herzog jedzie wraz z dwoma operatorami na francuską wyspę Gwadelupę. Efektem tej podróży będzie film z polskim tytułem Pod wulkanem. Podtytul: Czekanie na nieuniknionq katastrofe wprowadza nastrój katastroficzny. Autorska, spokojna, rzeczowa narracja nie pozostawia wątpliwości: rok 1976 był rokiem niezwykłych zdarzeń, katastrof: trzęsień ziemi, powodzi, tajfunów.

\footnotetext{
${ }^{36}$ Majmurek, Wiśniewska 2010, s. 165.

${ }^{37}$ Szczuka 2010, s. 91.
} 
Antropolodzy wiedzą, że poetyka czasu przedapokaliptycznego to przede wszystkim anomalie w naturze: trzęsienia ziemi, powodzie, epidemie, wybuchy wulkanów, „odwrócone" cykle natury (gorące zimy, lodowate lata). W aspekcie społecznym pojawiają się niejasne role społeczne, płeć staje się słabo rozpoznawalna, brak porozumienia z ludźmi, niezborność języków, samotność. Przyszłość jawi się jako pełna grozy. Mircea Eliade przekonywał: pojawia się wówczas, gdy następuje kryzys wartości; świat umiera, ale po to - jak nas uczą mity - by odrodzić się, zaistnieć od początku ${ }^{38}$. Wiesław Juszczak: „W każdym czasie umiera świat. W każdym momencie umiera człowiek. Umieranie świata nie jest końcem świata. Tylko postać świata przemija" ${ }^{39}$.

Topos apokaliptyczny jest szczególnie bliski odczuciom człowieka wieku XX. Katastrofizm końca kultury, wojenne „lekcje ciemności”, groza istnienia przyczyniły się do podejmowania poetyki apokaliptycznej w obszarze sztuk wszelakich.

Tak więc ryzykując, wówczas gdy prawie wszyscy naukowcy opuścili wyspę i ewakuowano 75 tysięcy osób, przybywa do Basse-Terre, osiemdziesięciodwutysięcznego miasta na południowym cyplu wyspy. Siedemnaście tysięcy mieszkańców ewakuowano, jeden z nich nie zgodził się opuścić miasta i Herzog postanowił go odszukać.

Herzoga naprawdę zajmują obrazy: introdukcja filmu prezentuje popiołową ziemię i monolityczny, ale paradoksalnie wrzący wulkan. Miasto jest puste. Kamera śledzi wyludnione ulice, poszczególne domy zawartymi drzwiami i okiennicami. Posterunek policji nie daje bezpieczeństwa, nikomu nie jest już potrzebny. Ewakuacja musiała być nagła: jeszcze działa w niektórych domach klimatyzacja, budki telefoniczne są czynne, działa sygnalizacja świetlna, puste wystawy sklepów, zostały tylko afisze reklamowe w salonie Baty. Miastem zawładnęły zwierzęta: osły, wygłodniałe psy i trupy zwierząt, które pewnie zmarły z głodu; przy nadbrzeżu morskim żadnego statku. W morzu tysiące węży. Herzog wyjaśnia, że wypełzły z lasu pod wulkanem i szukały ratunku w wodzie. Powoli wycofali się ostatni badacze wulkanu. Herzog ma jednak duszę dokumentalisty. Postanawia $\mathrm{z}$ wysokości helikoptera zrobić ostatnią panoramę miasta. I ponownie puste ulice, tym razem bogate domy, opuszczone ogrody. Filmuje wulkan z odległości $35 \mathrm{~km}$. Ale to zbyt mało, wyprawia się na wysokość $1300 \mathrm{~m}$ (wulkan liczy 1500). Podłoże gorące i niepewne. Obserwujemy obrazy dynamicznej działalności wulkanu, wydobywającej się zeń siarki.

Widz jest oszołomiony epifanijnymi krajobrazami Herzoga. To trochę tak jak u Blaise’a Cendrarsa: „Turystę ze starej Europy, gdzie przyroda jest kultywowana, a pejzaż wykalkulowany geometrycznie, oszałamia sam widok dziewiczego lasu, które uwięziło morze, potrząsa nim i kołysze" 40 .

Herzog uwiarygadnia ewakuację miasta opowieścią o dawnej rzeczywistej apokalipsie. W 1902 roku dramat dokonał się na sąsiedniej wyspie Martynika. Miasto Saint

\footnotetext{
${ }^{38}$ Zob. Eliade 2009, s. 79.

${ }^{39}$ Juszczak 2015, s. 212.

${ }^{40}$ Cendrars 1973, s. 154.
} 
Pierre, piękne, zadbane „z torem wyścigowym i operą”. Również położone u stóp wulkanu. $Z$ powodu już raz odłożonych wyborów, burmistrz przekonał ludzi by pozostali. Wyjechali tylko nieliczni. Ostatnie archiwalne zdjęcia miasta, które Herzog prezentuje z uważną powolnością zrobiono na dwa dni przed wybuchem. Następne zdjęcia to obraz krążących sępów, opadających w dół, ku miastu. Zatonął kanadyjski statek - informuje Herzog - który przybył po tych, którzy zechcieliby odpłynąć. Atak natury był tak nagły, że miasto znikło, 30 tysięcy ofiar z powodu podmuchu wulkanicznych gazów. Herzog pokazuje zdjęcia zrobione po apokalipsie: talerz z zastygłym spaghetti, chleb, który przemienił się w kamień. Ocalał jeden - najgorszy z mieszkańców. W miejscowym więzieniu zginęło 70 osób, on jako najtrudniejszy, zły, wtrącony został do podziemnej celi bez okien. Cierpiał latami, miał spalone tylne części ciała, nawet pokazywano go w cyrku.

Tam apokalipsa dokonała się; tu oczekujemy na niezwykły spektakl końca. W obrazach Herzoga jest jakaś niepohamowana kreatywność - pustka i groza dynamicznej góry. To prawda, że Herzog nigdy nie sięga do standardowych, sprawdzonych, konwencjonalnych obrazów. Cisza miasta, martwe, bo pozamykane okna, a wszystko jakby w kontrapunkcie niepozbawione jaskrawych kolorów i sierpniowej bujnej zieleni. Natura trwa, tylko jałowy jest pejzaż wulkaniczny, brutalnie jałowy. Być może dlatego budzi lęk, ale i fascynuje. Wydaje się, że Herzog wini li tylko naturę: pustkowie to obszar nieludzki, chaotyczny, gdzie formy uległy rozpadowi. W planach symbolicznych ziemia jałowa, popiół odnoszą się do utraty i braku kształtów, to metonimie śmierci ${ }^{41}$. Obserwując wulkan, przypomina, a może raczej tworzy obrazy natury bezforemnej, ale zawierającej zalążki wszystkiego; gdzie formy są w stanie wyłaniania się? To jednocześnie prakosmiczne i apokaliptyczne obrazy świata?

Umieranie świata to także sprawa ludzi. Herzog odnajduje nie tylko jednego, ale trzech, którzy pozostali w mieście. Główny bohater, leżąc pod drzewem w towarzystwie śpiącego kota, pozostał i czeka na śmierć. Widział już wiele i wiele wie. Czeka na tajfun, on poprzedzi śmierć miasta. „Bóg wyznaczył nam takie życie” - mówi. Tylko śmierć jest wieczna. Zaśpiewa Herzogowi dwie piosenki; szkoda, że dla widza pozostaną tajemnicą. Dwaj inni mówią to samo - nie mają prawie nic, zostali, by pilnować zwierząt, jeśli umrą, to $\mathrm{z}$ woli Boga.

Herzog ponownie przygląda się wulkanowi; hipnotyczne obrazy dymu, mgły wyłaniające się z fragmentów góry. Do wybuchu nie dochodzi. Znaki apokalipsy wycofują się. Film jest - twierdzi reżyser - , tylko wyczekiwaniem zapowiedzianej katastrofy”.

Ma rację Maria Janion, gdy mówi, że głównym tematem Mistrza jest obcość $\mathrm{w}$ świecie, właściwie - wydziedziczenie $\mathrm{z}$ życia ${ }^{42}$. To im, pozostałym w pustym mieście w zasadzie zadedykuje film. I choć idzie drogą transgresora - to zawsze ratuje go ironia. Herzog wie, że sztuka pod koniec XX wieku nie może istnieć bez ironii.

\footnotetext{
${ }^{41}$ Zob. Kowalski 2007, s. 499; Forstner 1990, s. 82-83.

${ }^{42}$ Wypowiedź M. Janion, w: Szczuka 2010, s. 99.
} 
Dążenie do absolutu podszyte jest ironią, twierdzi profesor Janion. W finale filmu Herzog powie, że w obrazie i słowie był patetyczny, a efekt okazał się żenujący, nic się nie wydarzyło. Czy na pewno?

\section{Lekcje ciemności}

To filmowa opowieść ukazująca „krajobraz po bitwie”. Herzog jedzie do Kuwejtu w początkach 1991 roku, po wojnie w Zatoce, zwanej Pustynną Burzą. Filmuje płonące szyby naftowe i pracę strażaków, którzy walczą z ogniem. O tym filmie napisano wiele tekstów. Bez wątpienia jest to jeden z najbardziej kreacyjnych dokumentów europejskiego kina. Niezwykle „malarski”, ekspresyjny, groźny. Mottem stają się słowa Pascala: „Upadek światów gwiezdnych dokona się jak ich stworzenie, w doskonałej piękności” ${ }^{3}$.

Materialność żywiołu ognia, materialność tego, co wydobywa się z głębi ziemi, pustynia zalana ropą naftową, która bulgocąc, wydobywa się na powierzchnię, tworząc rozlewiska błyszczące i imitujące jeziora. Jedni widzą w opowieści Herzoga rzecz o chaotycznej ciemności, o kreowaniu obrazów końca. Inni piszą: „Herzog schodzi (...) do tego, co najbardziej w nas ukryte, do stanów sprzed języka, do chaotycznej ciemności spoczywającej u początków procesu ustanawiania człowieka i świata" ${ }^{4}$. Dariusz Czaja wskazuje na funkcję poznawczą filmowych obrazów, którym towarzyszy tekst Janowej Apokalipsy, tej jednej z „najważniejszych matryc historiozoficznych świata zachodniego - niedwuznacznie wskazuje kierunek i cel historii: »ten świat« czeka nieodwołalny koniec" ${ }^{35}$. Apokalipsa to odkrycie, odsłonięcie:

Dokument Herzoga nie jest w żadnym razie utworem terapeutycznym, jakąś przestrogą, (...) ale raczej trzeźwym świadectwem ontologicznej ułomności tego świata. Opowiada o rzeczywistości eschatologicznej o tyle, o ile w przymiotniku eschatos będziemy akcentować znaczenia takie jak „krańcowy”, ,graniczny” i odnosić je do ekstremalnych wymiarów ludzkiego doświadczenia. W naturze tego typu doświadczeń leży to, że ludzkie spotyka się tu z nie - ludzkim, czas historyczny jakby sam siebie przekracza, wskazując na inną, już niemieszczącą się w porządku czasowym rzeczywistość ${ }^{46}$.

Zgadzam się, że skłonność do myślenia o wojnie w terminach apokaliptycznych jest „dyspozycją powszechną i trwałą” ${ }^{47}$. Są jednak w tym filmie ważne obrazy, które głęboko zapadają w pamięć. Obrazy nowe, nieznane dotąd, być może odwołujące się do początków kultury i początków człowieczeństwa, z Epoki Obrazu sprzed Epoki Sztuki4 ${ }^{48}$.

\footnotetext{
${ }^{43}$ Cyt. za: Czaja 2009, s. 285.

${ }^{44}$ Kopkiewicz 2010, s. 42.

${ }^{45}$ Czaja 2015, s. 12.

${ }^{46}$ Czaja 2009, s. 290.

${ }^{47}$ Czaja 2009, s. 289.

${ }^{48}$ Zob. Belting 2010.
} 
Zniszczone fragmenty dawnych urządzeń służących człowiekowi, zebrane i eksponowane dla potrzeb filmu (w muzeum?) przedmioty służące do tortur, pejzaże ascetyczne wypalonej ziemi. Pojawia się starsza kobieta. Herzog portretuje ją w manierze World Press Photo. Utraciła dwóch synów, torturowanych zabito w jej obecności. Herzog wyjaśnia, że odtąd zaniemówiła. Stara się opowiedzieć, co ją spotkało, dać świadectwo. Milczenie przerywa bowiem kontakt ze światem. Ryszard Przybylski, pisząc o pustelnikach, musi skonfrontować się z semantyką milczenia. Mowa jest triumfem ciała, bez mowy człowiek jest bezcielesny (to dlatego mowa dla mnicha jest tak groźna jak jego własne ciało). Dopiero kiedy zniknie materia, mowa opuści ciało ${ }^{49}$. Kobieta wydobywa słowa, ale to tylko pierwsza mowa dziecka, sylaby, westchnienia. Ręce idą w sukurs, chce nimi wyrazić coś poza słowem (a wszystko w statycznym ujęciu portretowym, w niemalże unieruchomionym kadrze), taniec rąk. W „lekcjach ciemności”, w czasie apokalipsy naturalny związek egzystencji ludzkiej i mowy został przerwany. Kobieta nie panuje nad słowami, ale „coś” mówi przez nią. Moc zostaje odnaleziona w niemocy - tak o rytualnym bełkocie mówił Gerardus van der Leeuw. Ten obraz ma walor mistyczny, „mistyka w ogóle szuka milczenia" ${ }^{50}$.

\section{Nowa ikonosfera. Posłowie}

Hans Belting był przekonany, że jesteśmy uformowani przez Erę Sztuki, zapomnieliśmy o Erze Obrazu. I choć powrót jest niemożliwy, to w centrum poszukiwań Wernera Herzoga pozostaje obraz wraz z jego epifaniczną mocą.

W centrum tego, co robię, leży poszukiwanie. Grubo upraszczając, podzieliłbym to na dwa wymiary. Po pierwsze, próbuję artykułować obrazy, których nam koniecznie potrzeba, ponieważ wleczemy się z tyłu za aktualnym stanem naszej cywilizacji. A kiedy nie mamy adekwatnego języka czy precyzyjnych, adekwatnych obrazów stanu cywilizacji, to jest to poważna sprawa. Wówczas cywilizacja wymiera niczym dinozaury. Po drugie, próbuję badać i szukać, kim my właściwie jesteśmy jako ludzie ${ }^{51}$.

By móc tworzyć nowy język filmowych obrazów, trzeba przekraczać granice: obrazów konwencjonalnych, obrazów wzmacniających nasze stereotypowe przyzwyczajenia wizualne. Bohaterowie dzieł Herzoga to byty transgresyjne; o tym pisano i o tym też wspomniałam. Myślę o Herzogu jako wielkim transgresorze, którego krajobrazy dążą do ujawniania stanów wewnętrznych. Krytycy często mówią o korzystaniu z podświadomości, snu, onirycznych lotów ${ }^{52}$. „Herzog zdaje się mówić, iż prawdę ustanawia

\footnotetext{
${ }^{49}$ Zob. Przybylski 1994, s. 87-88.

${ }^{50}$ van der Leeuw 1997, s. 378.

${ }^{51}$ Pflaum 2010, s. 14.

52 Zob. np.: Czaja 2009; Czaja 2015; Szczuka 2010.
} 
przekroczenie normy, tylko tak możliwe jest poznanie i bycie poza «się». (...) Doświadczenie transgresji to akt wolności naznaczony męczeństwem, zwieńczony odkryciem odchłannej prawdy" ${ }^{33}$. Budując „nowe obrazy”, chce dojść do źródeł kultur, tak jakby świat powinien zaistnieć od początku. Ustanowienie nowej widzialności to bezmiar poszukiwań, stąd podróże do „odwiecznych” kultur i dziewiczej natury.

Odrzucenie skonwencjonalizowanych form wizualnych i próba dotarcia do ,jądra ciemności” to bez wątpienia udręka artysty. Obrazy ziemi, która ujawnia swoje wnętrze, obrazy gór, których natura pogrąża w piekielnym ogniu - te obrazy chaosu odnoszą się do Epoki Obrazu, posiadają sakralną ambiwalencję i moc. Puste miasta przypominają senne wizje z obrazów surrealistów, ludzie bez cieni - to przecież ich ikonografia; Herzog wychodzi poza symbolizowanie. Ikonosfera „lekcji ciemności” to hipnotyczne obrazy końca, ale i chaosu początku, zdarzeń in illo tempore:

Magia to próba oswojenia świata, pierwotny odruch człowieka postawionego wobec zagadki istnienia. W tym kontekście odkrywanie nietkniętych przez cywilizację obrazów jest niemalże równoważne $\mathrm{z}$ gestem kreacji, a zniesienie granicy między podmiotem a przedmiotem stanowi swoisty akt wyzwolenia $\mathrm{z}$ porządku ustalonego przez racjonalny paradygmat kultury ${ }^{54}$.

Nowe obrazy, sięganie do początków rzeczywistości (jak na Antarktydzie, gdzie Werner Herzog zagłębia się w oceanie, chcąc doświadczyć - i nam to doświadczenie przekazać - stanu pierwotnego, sprzed kultury) z czasu, gdy życie w głębi oceanu musiało być piekłem tak strasznym, że w toku ewolucji - mówi w Deklaracji z Minessoty - niektóre gatunki wypełzły z wody i schroniły się na stałym lądzie - niewielkich kontynentach, ale nadal „lekcje ciemności” trwają ${ }^{55}$.

W tworzeniu „nowych obrazów” pomaga kontemplacja (bezruch, długie ujęcia, muzyka, barwy). Będąc w Indiach, próbuje konstrukcji „wewnętrznych” krajobrazów, korzystając z tradycyjnej estetyki indyjskiej, w której występuje przekonanie, że sztuka posiada zdolność odzwierciedlania rzeczywistości absolutnej. Wiązało się to z teorią rasa, czyli „smaków artystycznych, sprawiających, że dosłowność przedstawień scenicznych ulega w umyśle widza procesowi uogólnienia tak, że dokonuje się przeniesienie w wymiar duchowy" ${ }^{56}$.

Ma rację Artur Żmijewski, gdy mówi, że Herzoga charakteryzuje „nadwzroczność”, dodam - tak charakterystyczna forma transgresji. Herzog dzięki „nadwzroczności”

\footnotetext{
${ }^{53}$ Sarbiewska, 2014, s. 59, 61.

${ }^{54}$ Uszyński 1986, cyt. za: Sarbiewska 2014, s. 75.

${ }^{55}$ Zob. Herzog 2010, s. 113; Czaja 2013.

${ }^{56}$ Czapliński 1994, s. 64-65. Patrz także: Eco 2008, s. 64-81.
} 
doświadcza epifanii i tworzy je. Sięga do świata archetypów, do wiary w moc obrazów, co nigdy nie umniejsza, raczej udoskonala, uwiarygadnia przesłanie dla nas współczesnych. Jeszcze raz Artur Żmijewski: „Herzog zna kod dostępu. Jest w dobrej komitywie z siecią symbolicznych powiązań. $Z$ językiem kina, te filmy są ekwiwalentem tekstu naukowego, analitycznego, ale jednocześnie zawierają w sobie zdziwienie i grozę" ${ }^{\text {7 }}$.

Potrzebujemy w antropologii nowych sposobów filmowego obrazowania, opisu, interpretacji, ale także „zdziwienia i grozy”, zdobycia się na artystyczne gesty transgresji poza racjonalnym paradygmatem kultury. Od dawna wiemy, że dychotomia nauka / sztuka w XX wieku uległa osłabieniu. Nauka zbyt długo mówiła do twórców filmowych z protekcjonalnym lekceważeniem. Uczę się od Wernera Herzoga - wiem, że sztuka ma zdolność produkowania wiedzy. Wiem także, że tylko artysta może dokonać ożywienia doświadczeń mitycznych „w świecie zdominowanym przez światopogląd naukowy. Niemniej sztuka nie może zaoferować zupełnego powrotu do świadomości mitycznej”58 - pisze Andrzej P. Kowalski, omawiając myśl Ernsta Cassirera. Jest kilka aspektów różniących sztukę od mitu; chociaż sztuka może sprzyjać intensyfikacji, to nie ogranicza się tylko do wyrazu emocji. Jest ona twórczą umiejętnością „odnajdowania stosownego medium pozwalającego przeobrazić subiektywne doznanie w obiektywną postać" ${ }^{9}$. Mit zaś to forma totalizująca sposób doświadczania świata. Sztuka w odróżnieniu od mitu zawiera potencjał wolności, a jej celem - zniesienie granic i:

uzależnienie od czystej subiektywności i stworzenie możliwości obiektywizacji tego doświadczenia w formie artystycznej. (...) Sztuka zatem w zupełnie inny sposób niż mit odsłania przed człowiekiem dziedzinę jego oczekiwań, (...) zupełnie inaczej osadza człowieka w granicach poszukiwanej przez niego prawdy bycia. Unikalną właściwością sztuki jest dostarczanie coraz to nowej (podkreślenie - E.N.-S.) prawdy o człowieku i jego świecie. Właśnie ów uwalniający i zarazem twórczy aspekt sztuki w dziele ukazywania owej prawdy pozwala jej na rezygnację z postulatów mitycznych ${ }^{60}$.

Herzog dokonuje ożywienia świadomości mitycznej, mając świadomość, że pełnego powrotu do Epoki Obrazu nie ma. I choć doceniam klasyczne dzieła dokumentu etnograficznego, to poszukuję nadal filmu etnograficznego również poza etnografią.

Pisane w kwietniu 2020, w czasie pandemii.

\footnotetext{
${ }^{57}$ Wypowiedź A. Żmijewskiego, w: Majmurek, Wiśniewska 2010, s. 171.

${ }^{58}$ Kowalski 2014, s. 285.

${ }^{59}$ Kowalski 2014.

${ }^{60}$ Kowalski 2014, s. 285-286.
} 


\section{Bibliografia}

Belting H. 2010, Obraz i kult, Wydawnictwo Słowo/obraz terytoria, Gdańsk.

Bochmann G. 1994, Cztowiek na wulkanie. Portret Wernera Herzoga, [w:] P.C. Seel, B. Zmudzinski (red.), Werner Herzog, Wydawnictwo „Secesja”, Kraków.

Campbell J. 2004, Mityczny obraz, Wydawnictwo KR, Warszawa.

Cendrars B. 1973, Nie wierze wtasnym oczom. Historie prawdziwe, Wydawnictwo Czytelnik, Warszawa.

Cirlot J.E. 2000, Stownik symboli, Wydawnictwo Znak, Kraków.

Czaja D. 2009, Lekcje ciemności, Wydawnictwo Czarne, Wołowiec.

Czaja D. 2013, Znaki szczególne. Antropologia jako ćwiczenie duchowe, Wydawnictwo Uniwersytetu Jagiellońskiego, Kraków.

Czaja D. 2015, Figury końca. Przybliżenia, [w:] D. Czaja (red.), Scenariusze końca. Zmierzch, kres, apokalipsa, Wydawnictwo Czarne, Wołowiec, s. 7-23.

Czaja D.,Juszczak W.2017, Ruiny czasu. Rozmowy o twórczości, Wydawnictwo Czarne, Wołowiec. Czapliński J. 1994, Kino i jego sobowtór. O aspekcie transcendentnym filmów Herzoga, [w:] P.C. Seel,

B. Zmudzinski (red.), Werner Herzog, Wydawnictwo „Secesja”, Kraków.

Eco U. 2008, Sztuka, Wydawnictwo M, Kraków.

Eliade M. 2009, Traktat o bistorii religii, Wydawnictwo Aletheia, Warszawa.

Forstner D. 1990, Świat symboliki chrześcijanskiej, Instytut Wydawniczy PAX, Warszawa.

Herzog W. 2010, Deklaracja z Minessoty. Prawda i fakt w kinie dokumentalnym, [w:] Herzog.

Przewodnik Krytyki Politycznej, opracowanie zbiorowe, Wydawnictwo Krytyki Politycznej, Warszawa, s. 112-114.

Juszczak W. 2015, Przemijalna postać świata. O Satyriconie Felliniego, [w:] D. Czaja (red.), Scenariusze końca. Zmierzch, kres, apokalipsa, Wydawnictwo Czarne, Wołowiec, s. 207-213. Kopkiewicz A. 2010, Lodowe i piaszczyste pustynie Wernera Herzoga, [w:] Herzog. Przerwodnik Krytyki Politycznej, opracowanie zbiorowe, Wydawnictwo Krytyki Politycznej, Warszawa, s. 34-47.

Kowalski A.P. 2014, Antropologia zamierzchtych znaczeń, Polskie Towarzystwo Historyczne, Toruń.

Kowalski P. 2007, Kultura magiczna. Omen, przesq̨, znaczenie, Wydawnictwo Naukowe PWN, Warszawa.

van der Leeuw G. 1997, Fenomenologia religii, Wydawnictwo Książka i Wiedza, Warszawa.

Majmurek J. 2010, Prawda i technika, [w:] Herzog. Przewodnik Krytyki Politycznej, opracowanie zbiorowe, Wydawnictwo Krytyki Politycznej, Warszawa, s. 135-146.

Majmurek J., Wiśniewska A. 2010, Rozmowa z rzeczywistościq. Z Arturem Żmijewskim rozmawiaja Jakub Majmurek i Agnieszka Wiśniewska, [w:] Herzog. Przewodnik Krytyki Politycznej, opracowanie zbiorowe, Wydawnictwo Krytyki Politycznej, Warszawa, s. 162-172.

Nowina-Sroczyńska E. 2015, Hipnotyczne, nieregularne pejzaże Księcia, [w:] J. Barański, M. Golonka-Czajkowska, A. Niedźwiedź (red.), W krainie metarefleksji. Księga poświęcona 
profesorowi Czestawowi Robotyckiemu, Wydawnictwo Uniwersytetu Jagiellońskiego, Kraków, s. 571-583.

Pflaum H.G. 2010, Jestem dość spójny. Z Wernerem Herzogiem rozmawia Hans Günter Pflaum, [w:] Herzog. Przewodnik Krytyki Politycznej, opracowanie zbiorowe, Wydawnictwo Krytyki Politycznej, Warszawa, s. 6-27.

Przybylski R. 1994, Pustelnicy i demony, Wydawnictwo Znak, Kraków.

Sarbiewska J. 2014, Ontologia i estetyka filmowych obrazów Wernera Herzoga, Wydawnictwo słowo/ obraz terytoria, Gdańsk.

Seel P.C., Zmudzinski B. (red.) 1994, Werner Herzog, Wydawnictwo „Secesja”, Kraków.

Słodowski J. 1994, Fenomen egzystencji - fenomen kultury, [w:] P.C. Seel, B. Zmudzinski (red.), Werner Herzog, Wydawnictwo „Secesja”, Kraków.

Stownik terminów literackich 2004, A. Nawrot (red.), Wydawnictwo Greg, Kraków.

Szczuka K. 2010, Kaspar David Friedrich po Holokauscie. Z Maria Janion rozmawia Kazimiera Szczuka [w:] Herzog. Przewodnik Krytyki Politycznej, opracowanie zbiorowe, Wydawnictwo Krytyki Politycznej, Warszawa, s. 90-99.

Szymborska W. 2010, Wiersze wybrane, Wydawnictwo a5, Kraków.

Uszyński J. 1986, Herzogowska antropologia, „Film na Świecie”, nr 331.

Autorka:

dr hab. Ewa Nowina-Sroczyńska, prof. U£

Instytut Etnologii i Antropologii Kulturowej, Uniwersytet Łódzki

ul. Lindleya 3/5, 90-131 Łódź,

e-mail: nowinasroczynska@gmail.com 
